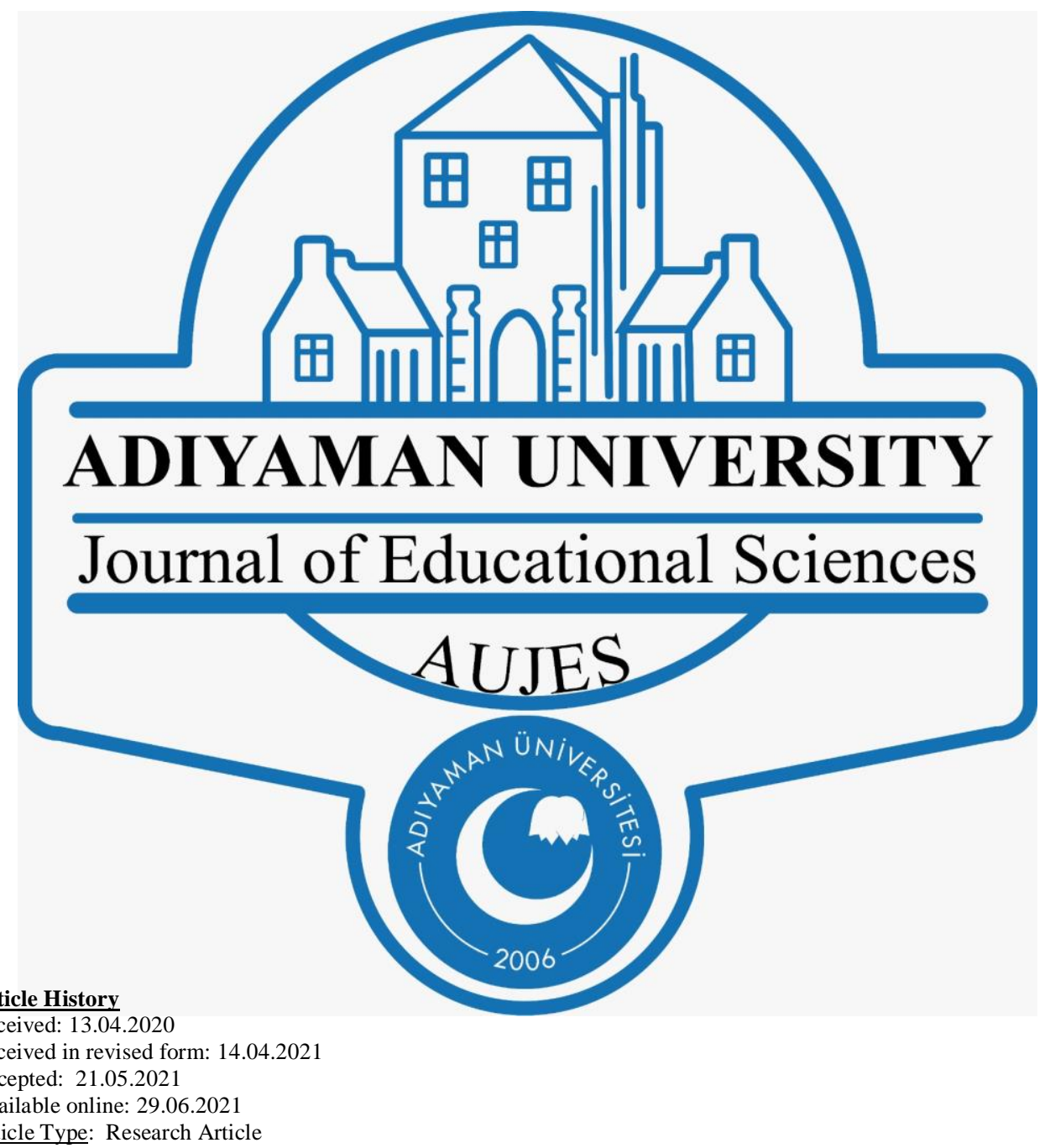

https://dergipark.org.tr/tr/pub/adyuebd

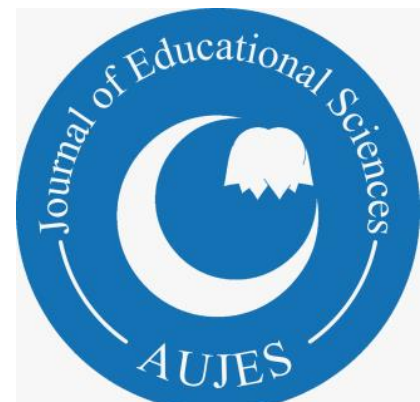

ADIYAMAN UNIVERSITY Journal of Educational Sciences (AUJES)

\title{
Determination of Cognitive Structures
} and Misconceptions of Pre-service Science Teachers' Regarding the Concept of "Energy"

Filiz Avcı ${ }^{1}$,

${ }^{1}$ İstanbul University-Cerrahpaşa, Mathematics and Science Education Department, Istanbul, Turkey

To cite this article:

Avc1, F. (2021). Determination of cognitive structures and misconceptions of preservice science teachers' regarding the concept of "Energy". Adiyaman Univesity Journal of Educational Sciences, 11(1), 9-25. 



\title{
Determination of Cognitive Structures and Misconceptions of Pre-service Science Teachers' Regarding the Concept of "Energy"
}

\author{
Filiz Avcı ${ }^{1 *}$, \\ ${ }^{1}$ Istanbul University-Cerrahpaşa, Mathematics and Science Education Department, Istanbul, Turkey
}

\begin{abstract}
The concept of "Energy", which is one of the concepts directly related to vital activities increases in importance day by day with the increasing technology and industrialization. For this reason, the concept of "Energy" learned in primary, secondary and higher education programs has a privileged place in science education as being an interdisciplinary concept. The aim of this study is to reveal the cognitive structures of pre-service science teachers about the concept of "Energy" and to determine their misconceptions. In the study, a survey model was used. The research was carried out with 95 pre-service teachers studying in the 3rd and 4th grade of the faculty of education, science education program of a public university in 2018-2019. The data were collected using the word association test (KIT) and the drawing-writing technique. The data were categorized with the content analysis method. The model explaining the cognitive structures of pre-service science teachers about the concept of "Energy" was prepared with the Vue program. As a result of the word association test about the concept of "Energy", the cognitive structures of the teacher candidates; It has been determined that it focuses on the categories of "Energy types", "Scientific terms evoking the concept of energy" and "Energy sources". In the study, it was determined that pre-service teachers had various misconceptions about the concept of "Energy" in the data obtained from both the word association test and the drawings. It is recommended to create learning environments that will ensure correct and meaningful learning by emphasizing conceptual learning
\end{abstract}

Key words: Energy, Cognitive structure, Word association test, Drawing-writing technique, Misconception

\section{Introduction}

The aim of science education is to raise individuals who can understand and transfer scientific knowledge correctly, think, question, develop problem solving skills, keep up with technological developments, establish a cause and effect relationship, and have a contemporary scientific perspective (Balbağ, Leblebiciler, Karaer, Sarıahya \& Erkan, 2016). Providing science education effectively is only possible with the complete and correct learning of the concepts. In this context, it is clear that establishing and revealing cognitive structures by establishing the correct relations between concepts plays a key role in the realization of conceptual learning.

Shavelson (1974) defines cognitive structure as theoretical structures that show the conceptual relationships in learners' long-term memories. Determining cognitive structures is very important in ensuring that science educators understand how learners receive and construct information (Tsai \& Huang, 2002).

In order to determine the cognitive structures; Alternative measurement and evaluation tools such as word association test, branched tree, structured grid, concept maps, conceptual change texts, questionnaires, and interviews are used (Bahar, 2003). Among these tools, the most used tools are the word association test (Gussarsky \& Gorodetsky, 1990; Işıklı, Taşdere \& Göz, 2011; Köseoğlu \& Bayır, 2011; Kurt, 2013) and the drawing-writing technique (Çetin, Özarslan, Işık \& Eser, 2013; Patrick \& Tunnicliffe, 2010; Smith \& Metz, 1996). With the word association test, it can be determined whether the relationships between the concepts in the long-term memory are at a sufficient level while revealing the relationships between the cognitive structures of individuals related to concepts and the concepts (Balbağ, 2018; Cardellini \& Bahar, 2000; Shavelson, 1974). In this context, misconceptions can also be detected with independent word association tests (Bahar \& Özatll, 2003; Ercan \& Taşdere, 2010). Nakiboğlu (2008) stated that using traditional assessment and evaluation methods is not enough to reveal the cognitive structures of learners, and word association tests are a convenient method for revealing the conceptual change of learners as well as determining the reflections of cognitive structures. When the drawing and writing technique is used, it can be provided to reveal the visual images of individuals related to their cognitive structures towards concepts (Özden, 2009; Patrick \& Tunnicliffe, 2010;

*Corresponding Author: Filiz Avcl, filizfen@istanbul.edu.tr 
Reiss \& Tunnicliffe, 2001). For this reason, the study carried out, it was aimed to obtain multidirectional data by using the word association test and the drawing-writing technique.

While learning is taking place, individuals may also embed unscientific concepts in their cognitive structures while constructing scientific and correct concepts.These non-scientific concepts are called "misconceptions" or "alternative concepts" (Nussbaum \& Novick, 1982; Skelly \& Hall, 1993). Misconceptions are expressed as behaviors resulting from false beliefs and experiences (Baki, 1999), and in a different definition, they are expressed as information that is incompatible with scientific facts and prevents the teaching and learning of concepts that have been proven by scientists (Chi \& Roscoe, 2002; Çakır \& Yürük, 1999). Studies in the literature show that learners have difficulty in forming their cognitive structures (Stavridou \& Solomonidou, 1998; Tsai \& Huang, 2002). While forming the cognitive structure, the fact that the information to be learned is abstract is one of the leading factors that affect learning negatively (Ekici \& Kurt, 2014). Physics, chemistry, biology, and science courses in science education include not only concrete concepts depending on the nature of each subject but also many abstract concepts. Abstract concepts cause the formation of wrong / incomplete or misconceptions in the cognitive structure of the learners and this situation creates a problem for both educators and learners (Yağbasan \& Gülçiçek, 2003).

The concept of "Energy", which is one of the abstract concepts directly related to vital activities; emerges as one of the most important issues and problems that human beings have emphasized from past to present. Today, the increase in technology and industrialization creates a need for more energy use. For this reason, the importance of learning and teaching the subjects related to energy sources, energy types, energy conversion, energy transmission and energy conservation increases more and more. With the increase in environmental problems in recent years, the concept of energy has started to come to the fore in the educational dimension. In the studies carried out for the concept of "Energy" at all education levels; it is seen that thoughts on the concept of energy are taken (Ayaz, Karakaş \& Sarıkaya, 2016; Güven \& Sülün, 2018; Kurnaz, 2007; Trumper, 1990; Lin \& Reping, 2003; Yürümezoğlu, Ayaz \& Çökelez, 2009), different learning-teaching methods are used to teach the concept of energy (Aydın \& Balım, 2005; Marulcu \& Höbek, 2014; Sarıca \& Çetin, 2012) and misconceptions are detected (Ayaz, Karakaş \& Sarıkaya, 2016; Chabalengula, Sanders \& Mumba, 2012; Solomon, 1982). The fact that "energy" can be associated with many different subjects is one of the main factors that make it attractive to work on.

One of the most important features of the concept of "energy" is that it is an interdisciplinary concept besides being an abstract concept. For this reason, it is learned in secondary education and higher education programs starting from primary education and has a privileged place in science education (Kılıç \& Cerit Berber, 2018; Sağlam Arslan, 2010; Töman \& Odabaş1, 2012). With science education, students have the knowledge that they can apply in their lives by making the basic science concepts concrete (Çoban, Aktamış \& Ergin, 2007). While the concept of "Energy" has various forms such as kinetic, potential, electricity, heat, light, chemical, sound and geothermal, the concept of "Energy" is defined by highlighting different forms in different disciplines. "Energy" is expressed as in chemistry lesson; the heat required to break the bonds between atoms while chemical reactions take place and the heat released when bonds are formed (Karaca and Göktan, 2007: p.77) in biology lesson; it is a concept that is needed for living creatures to survive and the sun is the main source (Sağdıç, Bulut, Korkmaz, Börü, Öztürk, \& Cavak, 2007: p.38) and in physics lesson; the ability to do business (Trefil \& Hazen, 2004). With a different expression, the "Energy" concept; is defined as a quantity with types such as kinetic, potential, electricity and nuclear energy (Şahan \& Tekin, 2007).

The concept of "energy" is included as subtopics in subjects belonging to various disciplines. For this reason, it is stated that students construct the concept differently and encounter difficulties in inter-subject association (Ayas et al., 2002). It is stated in the literature that the concept is considered difficult by students from different disciplines and levels due to its abstract nature (Stylianidou, 2002; Opitz, Harms, Neumann, Kowalzik, \& Frank, 2015; Yuenyong \& Yuenyong, 2007; Yürümezoğlu, et al., 2009). Solomon (1982) found that because the concept of energy is abstract, learners memorize energy concepts without thinking at all. In studies conducted on the concept of "Energy" at primary, secondary and undergraduate levels, it was determined that students have misconceptions about energy sources, energy conversion, energy transmission and energy conservation (Opitz, Blankenstein, \& Harms, 2017; Solomon, 1982; Toman, Karatas, and Çimer, 2013; Trumper, 1990; Trumper, 1998). Kruger (1990), as a result of the study of 20 primary school teachers' thoughts on the concept of energy, found that teachers had misconceptions such as "energy is about movement", "energy is stored force", "energy is not conserved". Köse, Bağ, Sürücü and Uçak (2006) as a result of the study in which they aimed to determine the misconceptions of science teacher candidates regarding energy and energy resources, found that plants and animals have misconceptions about where they get energy. In the same study, it was stated that most of the pre-service science teachers focused on the concept of energy in physics. Ünal Çoban Aktamış and Ergin (2007) emphasized in their study that there are difficulties in understanding the concept of 
"Energy" because it is an interdisciplinary subject and that it should be handled with its physical, chemical and biological dimensions in order to overcome difficulties.

When the studies in the literature are examined; It is seen that there are studies in which cognitive structures for the concept of "Energy" are put forward and the level of conceptual understanding is examined by using different methods and techniques at different learning levels. In the studies, the questionnaire consisting mostly of open-ended questions, multiple choice test and interview technique (Duit, 1984; Kruger, 1990; Kurnaz, 2007; Opitz, Harms, Neumann, Kowalzik, \& Frank, 2015; Toman \& Çimen, 2011; Yıldırım, Önal, \& Büyük, 2019; Yürümezoğlu et al., 2009), it was determined that a limited number of word association tests (Çardak, 2009; Uyduran, 2019) were used. A study conducted by Güven and Sülün (2018) with pre-service teachers in which the word association test and drawing and writing technique were used was found. However, in the literature review, there is no study in which the word association test and the drawing and writing technique for the concept of "energy" were used together and misconceptions were detected. In the literature, it is seen that there are misconceptions in students at all levels regarding the concept of "Energy". It is also very difficult to reveal the cognitive structures that will enable us to determine what misconceptions are. In this context, determining the opinions of individuals on the concepts is one of the prominent issues. With the word association test, these thoughts can be explained with words and can be explained visually with the drawing and writing technique. Considering that there are students who express their thoughts in different ways; this situation creates an opportunity to express the concepts in a multifaceted way. Thus, versatile data can be obtained to detect errors in students. In addition, students learn the concept of "Energy" in different lessons starting from primary school. "Science lesson" is the first lesson in which students encounter the concept of "Energy". Considering that they will see them in different courses in the future, they should be learned in the most conceptually correct way. For this reason, it is very important to determine whether the pre-service teachers who will teach in the secondary school science course know the concepts correctly. In this context, misconceptions were investigated by using the word association test and the drawing and writing technique together in the study. It is thought that the results of the study will contribute to the relevant literature by providing a different perspective.

The aim of this study is to determine the cognitive structures and misconceptions of pre-service science teachers about the concept of "Energy" by using the word association test and the drawing-writing technique.

In line with this main purpose, the following questions were sought:

- What are the cognitive structures of pre-service science teachers towards the concept of "Energy"?

- What are the misconceptions of pre-service science teachers about the concept of "Energy"?

\section{Method}

\section{Research Model}

A Survey model was used in this research. A Survey model is a research approach that aims to describe a situation that has existed in the past or still exists (Karasar, 1999). In the study, the data about the cognitive structures of pre-service science teachers for the concept of "Energy" was investigated in detail.

\section{Research Group}

The research was carried out with third and fourth grade students studying in the Science Teaching Department of a state university in the Marmara Region in the 2018-2019 academic year. The selection of the study group was influenced by the fact that the students studying in these classes had taken "General Chemistry, General Physics and General Biology" courses in previous years and were close to the teaching profession. This situation is suitable for purposeful sample selection. The purposeful sampling allows for the detailed investigation of situations that are thought to have versatile information (Yıldırım \& Şimşek, 2016). In this context, 95 volunteer students participated in the research.

\section{Data Collection Tools}

Word association test (WAT) and drawing-writing technique were used in order to reveal the cognitive structures of pre-service teachers regarding the concept of "Energy" and to determine their misconceptions. Before starting the application, explanations were made to the students about the WAT and the application of the drawing-writing technique, and application examples were given.

\section{Word Association Test}

Word association test consists of two parts. In the first part, the concept of "Energy" has been included, leaving gaps for students to write what they think about the concept. In the word association test, pre-service teachers should write the first ten words brought to mind by the main concept within 40 seconds (Gussarsky \& 
Gorodetsky, 1990). For this reason, pre-service teachers were given 40 seconds. The main concept is written on a single page. The reason for this situation; to prevent the possibility of chain response. If the pre-service teacher does not return to the main concept in every word writing, he can write the words that he wrote as an answer instead of the main concept (Bahar \& Özatlı, 2003).

In the second part, pre-service teachers were asked to write a sentence about the concept of "Energy" within 20 seconds. The reason for this is the possibility that the words related to the main concept can only be at the recall level or words that do not have a meaningful relationship with the main concept (Nartgün, 2006). In addition, since the "related sentence" written by pre-service teachers will have a more complex and higher level structure compared to a single word, whether the sentence is scientific or not and whether it contains misconceptions will affect the evaluation (Ercan \& Taşdere, 2010).

The WAT for the concept of "Energy" is organized as follows:

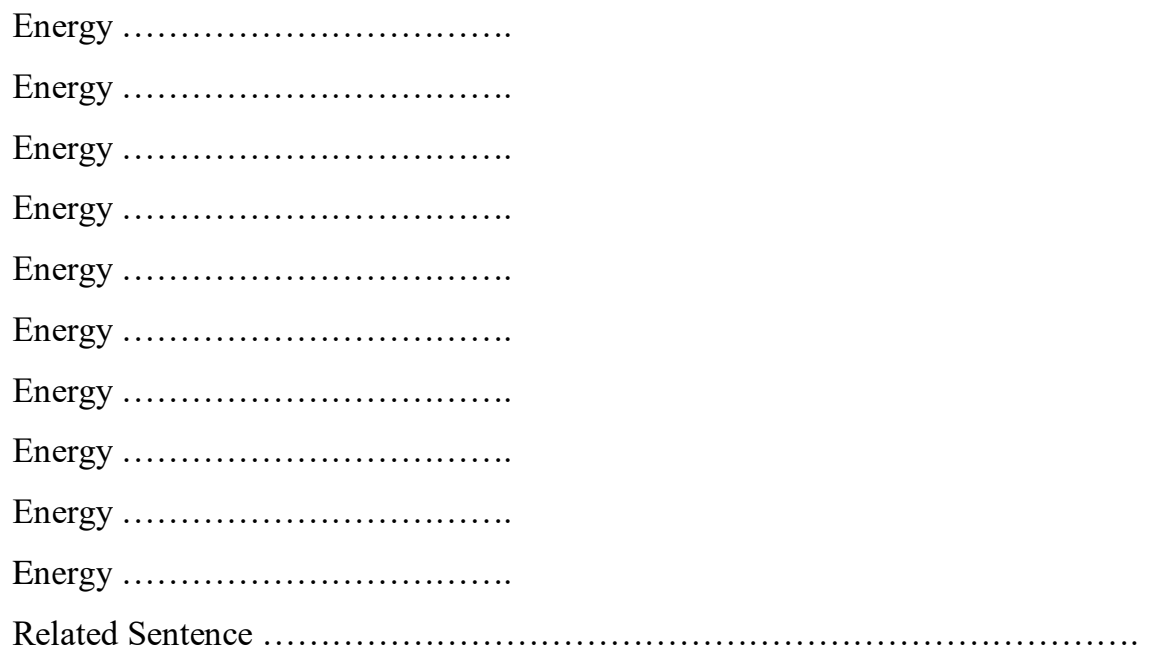

\section{Data Analysis}

The data collected with the measurement tool were analyzed by content analysis. Content analysis; It is a scientific method that enables objective and systematic evaluation of verbal, written and other materials (Tavşancıl \& Aslan, 2001). With content analysis, similar data are organized by gathering under certain concepts and categories (Lichtman, 2010). Content analysis; consists of processing data and extracting codes, creating themes, arranging codes and themes by associating them, defining the findings and making comments (Yıldırım \& Şimşek, 2016). All the data of the study were analyzed following these steps.

In the word association test, a frequency table expressing the frequency of repetition of the concepts used by pre-service science teachers concerning the concept of "Energy" was prepared. The words that were repeated only once by the participating pre-service science teachers and not related to other words and the subject were not taken into consideration (Kostova \& Radoynovska, 2008; Kurt, 2013). The reason for this; It is difficult to create a concept network consisting of meaningful categories from these words used in large numbers. In the analysis process, words were categorized using semantic relationship criteria. There are many studies in the literature showing that this type of data analysis technique gives reliable results (Kostova \& Radoynovska, 2008; Kurt, 2013). While analyzing the data, the model of the pre-service science teachers' cognitive structures related to the concept of "Energy" was prepared with the Vue program.

The sentences expressed by pre-service science teachers related to the concept of "Energy" were categorized as sentences containing scientific information, sentences containing non-scientific and superficial information, and sentences containing misconceptions, using the table developed by Ercan, Taşdere, and Ercan (2010).

If the related sentence is scientifically correct and related to the concept, the sentence containing scientific information; If it is not scientific, reflects feelings and thoughts used in daily life, unscientific and superficial sentence; If expressing the concepts using different and incorrect expressions, it is determined as a sentence containing misconception.

\section{Validity and Reliability Study}

Validity of research results; coding of data, detailed explanation of the analysis process (how to reach the conceptual category) (Hruschka, Schwartz, St. John, Picone-Decaro, Jenkins \& Carey, 2004) and it was provided by giving the opinions of the pre-service science teachers in the findings section. After the data of the 
study were coded separately by two science education experts, the code and category list were finalized. Reliability of data analysis; It was calculated using the formula [Agreement / (Agreement + Disagreement) $\mathrm{x}$ 100] (Miles \& Huberman, 1994). The average reliability between coders for the research performed was found to be $90 \%$.

\section{Results}

In this part of the research, the findings obtained by analyzing the data collected by the word association test and the drawing and writing technique are included.

\section{Findings Obtained According to the Word Association Test Data}

As a result of the analysis of the data showing the cognitive structures of the pre-service science teachers regarding the concept of "Energy", it was determined that they associated 80 concepts with the main concept of "Energy". These 80 concepts have been repeated 936 times in total. Among all concepts, 67 concepts that have been repeated 881 times were collected in 7 main categories. The category with the highest frequency among the specified categories is the category of "Energy types". This category is followed by "Scientific terms evoking the concept of energy", "Energy sources", "Situations that provides energy formation", "Properties of energy", "Contribution of energy to daily life" and "Affective effect of energy" categories. If these words are repeated once, if they are not meaningful and not related to the concept, they are not combined with other answer words (Kostova \& Radoynovska, 2008; Kurt, 2013). For this reason, 17\% (13 words) of the words given as answers were not included in the categories. Charge (7), universe (7), vibration (6), Chernobyl (6), particle (6), brain (5), effect (4), formula (4), acceleration (4), organism (2), explosion (2), reaction (1) and cell (1) the concepts that do not fall into any category were repeated 55 times in total. In this context, the distribution of the cognitive structures of the pre-service science teachers obtained by the word association test on the concept of "Energy" by categories is given in Table 1.

Table 1. The distribution of the cognitive structures of the pre-service science teachers obtained by the Word Association test on the Concept of "Energy" by categories

\begin{tabular}{|c|c|c|}
\hline Categories & $\begin{array}{l}\text { Included in the Categories } \\
\text { Concepts and Frequencies }\end{array}$ & $\begin{array}{l}\text { Total } \\
\text { Frequencies }\end{array}$ \\
\hline Energy types & $\begin{array}{l}\text { Potential Energy(58) } \\
\text { Kinetic Energy (55) } \\
\text { Heat Energy(37) } \\
\text { Mechanical Energy(35) } \\
\text { Motion Energy (32) } \\
\text { Electrical Energy (31) } \\
\text { Nuclear Energy (20) } \\
\text { Chemical Energy (20) } \\
\text { Light energy (20) } \\
\text { Sound Energy(5) } \\
\text { Geothermal Energy(4) }\end{array}$ & 317 \\
\hline $\begin{array}{l}\text { Scientific terms } \\
\text { evoking the concept } \\
\text { of energy }\end{array}$ & $\begin{array}{l}\text { Power (22) } \\
\text { Joule(21) } \\
\text { Mass (19) } \\
\text { Speed (15) } \\
\text { Work (15) } \\
\text { Temperature (13) } \\
\text { Calori (10) } \\
\text { Atom(10) } \\
\text { Force (10) } \\
\text { Einstein (6) } \\
\text { Energy pyramid (6) } \\
\text { Relativity (6) } \\
\text { Matter (5) } \\
\text { Newton(5) } \\
\text { Tesla(5) } \\
\text { Essence (5) } \\
\text { E=mc }{ }^{2}(5) \\
\text { Science (5) } \\
\text { Thermodynamics (5) }\end{array}$ & 208 \\
\hline
\end{tabular}




\begin{tabular}{|c|c|c|}
\hline & $\begin{array}{l}\text { Enthalpy (5) } \\
\text { Entropy (4) } \\
\text { Exothermic reaction (4) } \\
\text { Endothermic reaction (4) } \\
\text { Quantum(3) }\end{array}$ & \\
\hline Energy sources & $\begin{array}{l}\text { Sun (45) } \\
\text { Renewable energy sources (24) } \\
\text { Wind (21) } \\
\text { Non-renewable energy sources (10) } \\
\text { Battery (10) } \\
\text { Water (5) } \\
\text { Molecule breakdown }(5)\end{array}$ & 120 \\
\hline $\begin{array}{lr}\text { Situation } & \text { that } \\
\text { provides } & \text { energy } \\
\text { formation } & \end{array}$ & $\begin{array}{l}\text { Eating (25) } \\
\text { Collision of subatomic particles (13) } \\
\text { Human body (10) } \\
\text { Power Plants (8) } \\
\text { Mitochondria (6) } \\
\text { Friction (6) } \\
\text { Breathing (5) } \\
\text { Eating chocolate (5) } \\
\text { Fission-fusion (4) }\end{array}$ & 82 \\
\hline Properties of energy & $\begin{array}{l}\text { Conservation (27) } \\
\text { Transformation (20) } \\
\text { Produced (15) } \\
\text { Consumable (5) } \\
\text { Savings can be achieved (5) } \\
\text { Shopping (5) }\end{array}$ & 77 \\
\hline $\begin{array}{l}\text { Contribution of } \\
\text { energy to daily life }\end{array}$ & $\begin{array}{l}\text { Allows to live (19) } \\
\text { Physical activity (13) } \\
\text { Technology (5) } \\
\text { Photosynthesis (4) }\end{array}$ & 41 \\
\hline \multirow[t]{2}{*}{$\begin{array}{l}\text { Affective effect of } \\
\text { energy }\end{array}$} & $\begin{array}{l}\text { Positive energy(13) } \\
\text { Negative energy (5) } \\
\text { Love (5) } \\
\text { Metaphysics (5) } \\
\text { Dance pleasure (4) } \\
\text { Coffee enjoyment (4) }\end{array}$ & 36 \\
\hline & 67 & 881 \\
\hline
\end{tabular}

As seen in Table 1, according to the answers given by pre-service science teachers to the word association test, "Energy types" for the main concept of "Energy" was determined as the first category $(\mathrm{f}=317)$. Under this category, 11 words were determined. The first 6 words that are frequently repeated among these words are "potential energy", "kinetic energy", "heat energy", "mechanical energy", "motion energy" and "electrical energy". It was determined that other pre-service science teachers focused on the concepts of "nuclear energy", "chemical energy", "light energy", "sound" and "geothermal energy".

According to the answers given by pre-service science teachers to the word association test, "Scientific terms evoking the concept of energy" for the main concept of "Energy" was determined as the second category ( $f=208$ ). Under this category, 24 words were determined. The first 6 words that are most frequently repeated among these words are "power", "joule", "mass", "speed", "work", "temperature". It has been determined that other preservice teachers focus on the concepts of "calori ","atom”, “ force”, "Einstein”", “energy pyramid”, "relativity", "matter",Newton”, "Tesla","essence", "E=mc", "science", "thermodynamics", "enthalpy", "entropy", "exothermic reaction", "endothermic reaction" and "quantum".

According to the answers given by the pre-service science teachers to the word association test, for the main concept of "Energy", "energy sources" was determined as the third category ( $f=120)$. Under this category, 7 words were determined. The first 4 words that are most frequently repeated among these words are "Sun", 
"renewable energy sources", "wind" and "non-renewable energy sources". It was determined that other preservice science teachers focused on the concepts of "battery", "water" and "molecule breakdown".

According to the answers given by pre-service science teachers to the word association test, for the main concept of "Energy","Situations that provides energy formation" was determined as the fourth category (f = 82). Under this category, 9 words were determined. The first 3 words that are most frequently repeated among these words are "eating", "collision of subatomic particles" and "human body". It was determined that other preservice science teachers focused on the concepts of "power plants", "mitochondria", "friction", "breathing", "eating chocolate" and "fission-fusion".

According to the answers given by the pre-service science teachers to the word association test, for the main concept of "Energy", the "Properties of energy" was determined as the fifth category ( $\mathrm{f}=77$ ). Under this category, 6 words were determined. The first 3 words that are most frequently repeated among these words are "conservation", "transformation" and "produced". It was determined that other pre-service science teachers focused on the concepts of "consumable", "savings can be achieved" and "shopping".

According to the answers given by pre-service science teachers to the word association test, for the main concept of "Energy","Contribution of energy to daily life" was determined as the sixth category ( $\mathrm{f}=41$ ). Under this category, 4 words were determined. The word that is most frequently repeated among these words is the word "allows to live". It was determined that other pre-service science teachers focused on the concepts of "physical activity", "technology" and "photosynthesis".

According to the answers given by pre-service science teachers to the word association test, for the main concept of "Energy", "Affective effect of energy" was determined as the seventh category ( $\mathrm{f}=36$ ). Under this category, 6 words were determined. The most frequently repeated of these words is the word "positive energy". It was determined that other pre-service science teachers focused on the concepts of "negative energy", "love","metaphysics","dance pleasure","coffee enjoyment".

\section{Findings Regarding the Sentences That Pre-Service Science Teachers Made About the Concept of "Energy"}

In order to reveal the knowledge structures of the pre-service science teachers about the concept of "Energy" in detail, the sentences expressed concerning the concept of "Energy" were analyzed depending on their relationship with the concept and divided into categories according to their meanings. At this stage, while it was determined that some of the pre-service science teachers did not write sentences, most of the pre-service science teachers have defined the concept of energy and its types, explained the properties of energy, emphasized energy sources, and explained its usage areas in daily life.

When the sentences are evaluated under the specified categories;

The pre-service science teachers', according to the category of "Energy types"; it has been determined that have misconceptions such as "There are 3 types of energy: potential, kinetic and mechanical".

The pre-service science teachers', according to the category of "Scientific terms evoking the concept of energy"; has been determined that they have statements that contain scientific information such as "The unit of energy is Joule." and they have misconceptions such as "It is the power required for an object to do work.", "It is the force that exists in matter in the universe." and "It is what is necessary for living things to move".

The pre-service science teachers', according to the category of "Energy resources"; it has been determined that they have statements that contain scientific information such as "The sun is the most important source of energy.", "There are renewable and non-renewable energy sources." and "Wind is a renewable energy source."

The pre-service science teachers', according to the category of "Situations that provides energy formation"; it has been determined that they have statements that contain scientific information such as "As a result of breathing with oxygen, 38 ATP energy is obtained."

The pre-service science teachers', according to the category of "Properties of energy"; it has been determined that they have statements that contain scientific information such as "Energy cannot be created out of nothing and the existing energy cannot be destroyed.", "Energy can be converted." and "Energy is always conserved in the universe." and besides this, they have misconceptions such as "The energy is running out." and "Only living things have energy."

The pre-service science teachers', according to the category of "Contribution of energy to daily life"; it has been determined that they have statements that contain unscientific and superficial sentences such as "Energy provides living." 
The pre-service science teachers", according to the category of "Contribution of energy to daily life"; it has been determined that they have statements that contain unscientific and superficial sentences such as "Energy provides living."

The pre-service science teachers", according to the category of "Affective effect of energy"; it has been determined that they have statements that contain unscientific and superficial sentence such as "Life is beautiful thanks to the positive energies.","I have no energy today." and "Energy is enjoying coffee."

In this context, it can be said that pre-service science teachers have scientific knowledge about the concept of "Energy" but at the same time have quite a number of misconceptions. As a result of the analysis of the obtained data, a model was created that visualizes the cognitive structures of pre-service science teachers towards the concept of "Energy" (Figure 1).

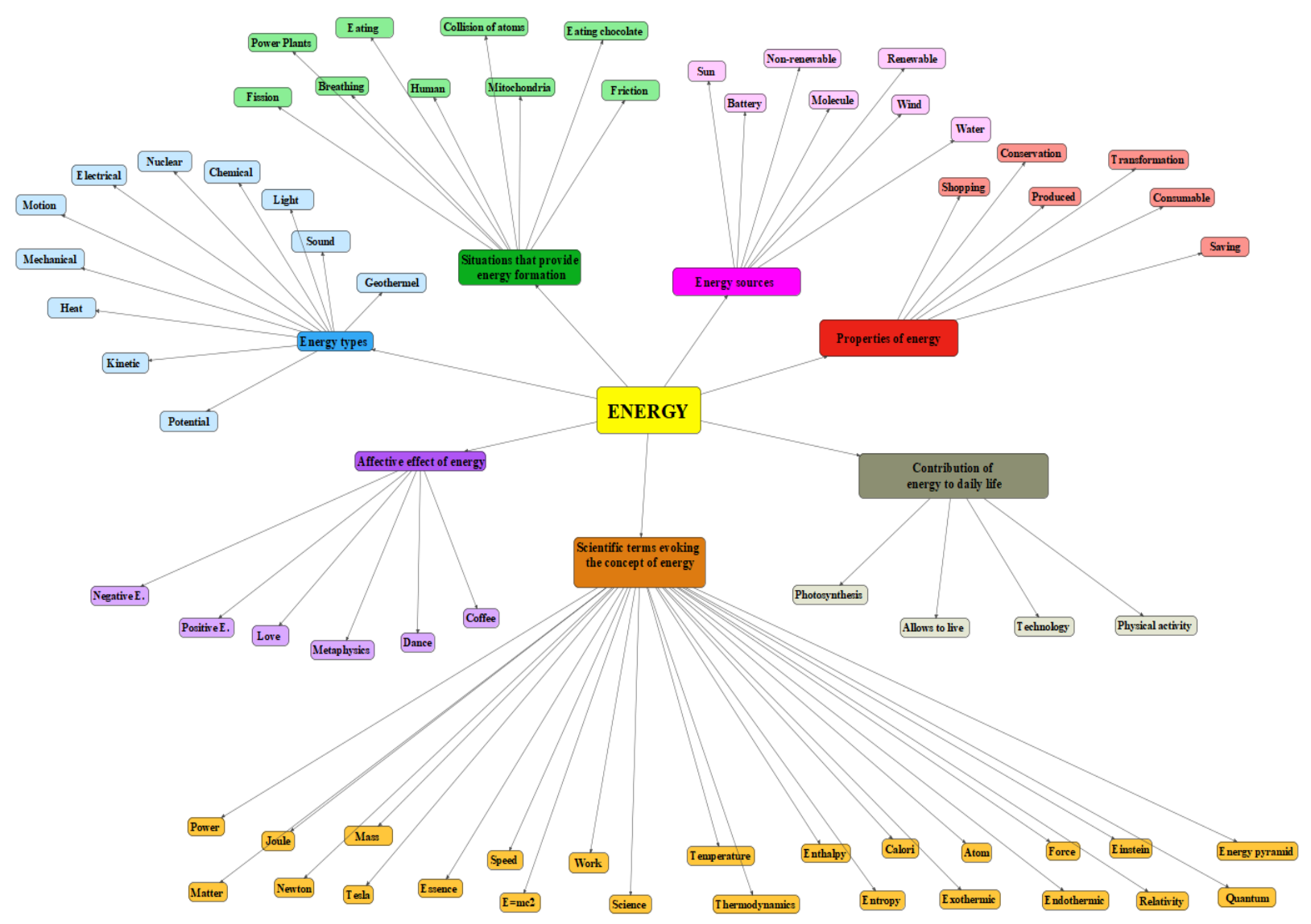

Figure 1. The cognitive structure of pre-service science teachers determined by the word association test on the concept of "Energy

As seen in Figure 1, the conceptual structures of pre-service science teachers related to the concept of "Energy" have emerged concerning 7 categories.

\section{Findings Obtained According to the Drawing-Writing Technique Data}

The conceptual structures created by the drawing-writing technique that support the cognitive model (Figure 1) associated with the concept of "Energy" of pre-service science teachers are shown in Figure 2. It was determined that the conceptual structures of the pre-service science teachers, for the concept of "Energy" are related to three categories. 


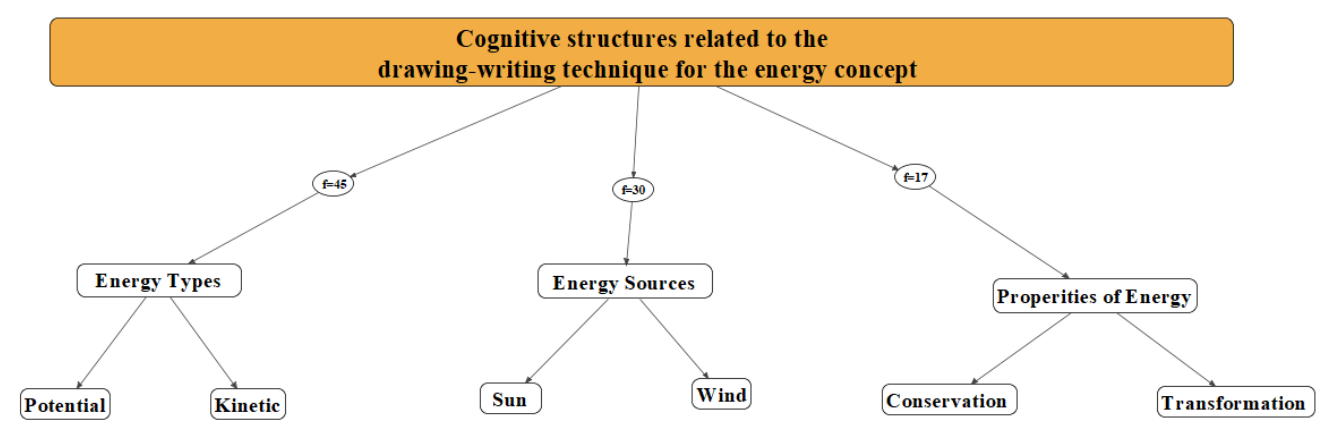

Figure 2. cognitive structure of pre-service science teachers determined by the drawing-writing technique related to the concept of "Energy"

The drawings of the pre-service science teachers on the concept of "Energy" were collected under 3 categories. These categories are; "Energy types (45)", "Energy sources (30)" and "Energy properties (17)". Examples of the drawings of the pre-service science teachers, related to the concept of "Energy", their categories and frequency values are shown in Table 2.

Table 2. Distribution of preservice science teachers' cognitive structure determined by the drawing-writing technique related to the concept of "Energy" and drawing samples

Categories Drawing concep Drawing samples $\quad$ f

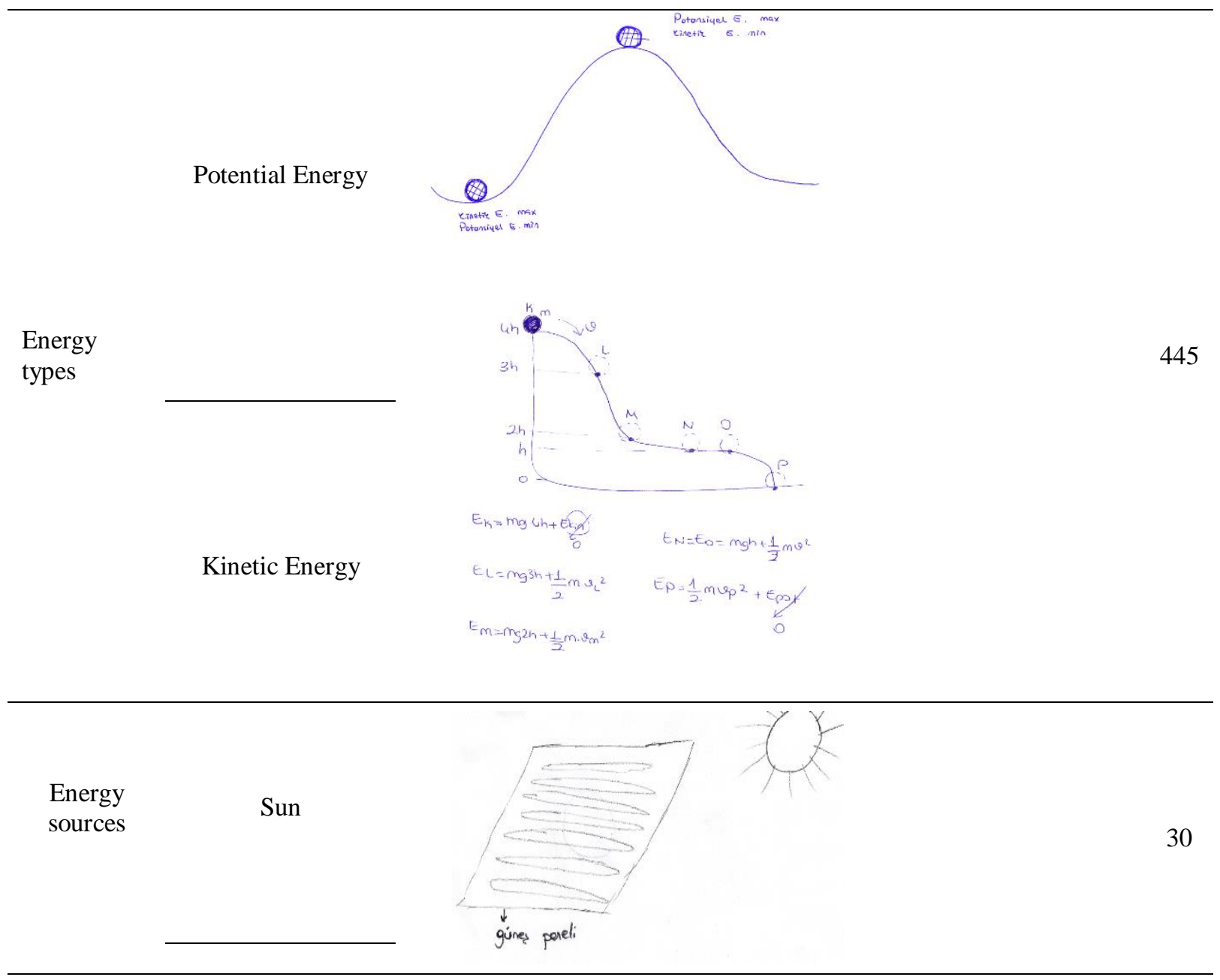


Wind

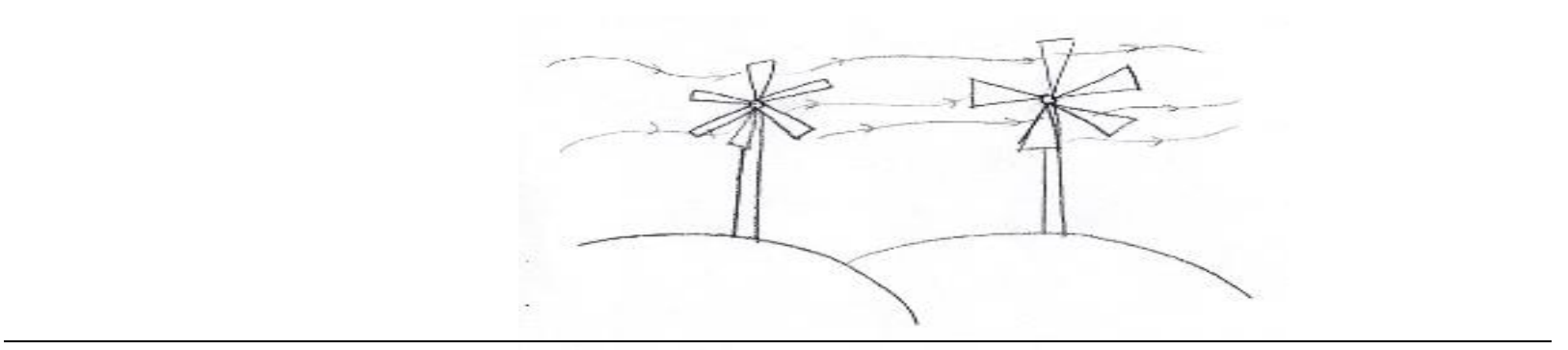

Conservation

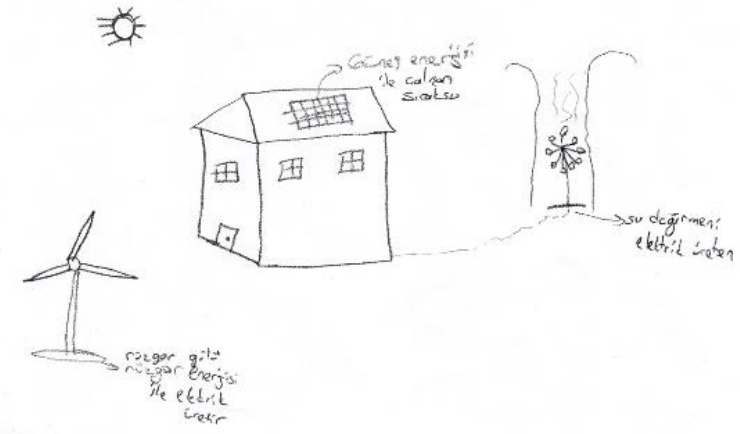

Properties of energy

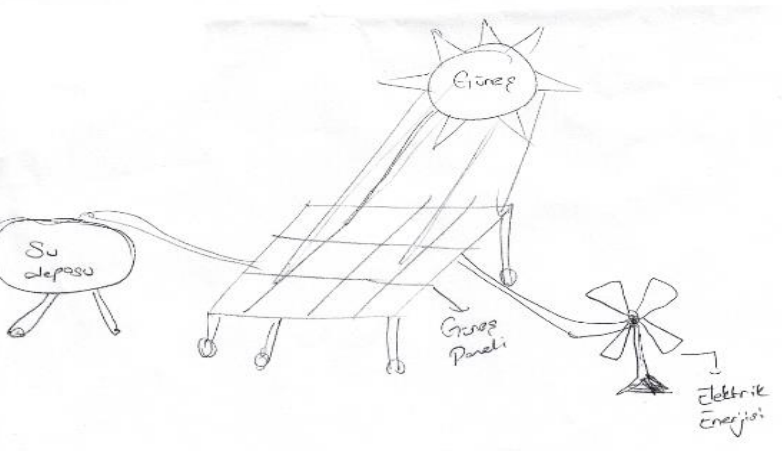

From the drawings of the pre-service science teachers, about the concept of "Energy"; it has been determined that they drew heavily thinking about energy types and in such a way that the concepts of potential and kinetic energy are dominant. These are followed by drawings related to energy resources, primarily wind and solar energy and it has been observed that they express the properties of energy at a low rate in a way to relate the conservation and transformation of energy.

\section{Discussion-Conclusion}

In this study, which aims to reveal the cognitive structures of pre-service science teachers related to the concept of "Energy" through word association test and drawing-writing technique, and to determine their misconceptions, multifaceted data supporting each other was obtained. In this context, the data obtained through the word association test are collected in 7 categories in total ("Types of energy", "Scientific terms evoking the concept of energy", "Energy sources", "Situations that provides energy generation", "Properties of energy", "Contribution of energy to daily life", "Affective effect of energy"), 3 categories were determined with the drawing and writing technique ("Types of energy","Energy sources", "Properties of energy"). When the categories were examined, it was determined that there were more categories obtained by the word association test. It has been determined that the categories of "Scientific terms evoking the concept of energy", "Situations that provides energy formation", "Contribution of energy to daily life" and "Affective effect of energy" did not appear in the drawing-writing technique. In the light of the answers received as a result of the application of both techniques; it has been determined that the pre-service science teachers, frequently concentrate on potential and kinetic energy types among energy types, on the sun, renewable energy sources, non-renewable energy 
sources and wind among energy sources, on conservation, transformation and production concepts regarding the properties of energy.

The obtained results show once again the importance of using various measurement tools in academic studies in a way that supports each other in order to obtain qualified data. In the study, while the students explained the word association test for the concept of "Energy" in writing, they also had the opportunity to express their thoughts by drawing in the drawing and writing test. Although the results support each other, the fact that some concepts that are not obtained in one technique can be obtained with another technique shows the richness of the data obtained from the study.

The pre-service science teachers' from the data obtained using the word association test and drawings about the concept of "Energy"; it has been determined that they have misconceptions and incomplete information such as "There are 3 types of energy, potential, kinetic and mechanical.", "It is the power required for an object to do work.", "It is the force that exists in the matter of the universe.","The energy is running out." and "Only living things have energy.". In parallel with these results obtained in the study, it was found that there were similar misconceptions in the results of the studies on the concept of "Energy" carried out with pre-service science teachers and students had difficulties in understanding the concept of energy (Kruger, 1990; Köse et al., 2006; Kurnaz, 2007; Töman and Çimen, 2011; Trumper, 1996; Trumper, 1998). It can be thought that the reason for this is that the concept is abstract and therefore they cannot form the different sub-concepts related to the concept in their mind in a holistic way or they cannot learn the subjects completely and correctly.

It was determined that pre-service science teachers focused on the concepts of potential energy and kinetic energy under the category of "Energy Types". It is seen that the number of students talking about other types of energy such as heat, mechanics, motion, and electricity is less. This result shows that students do not have enough information about energy types. Similar results were obtained when the drawings of the pre-service science teachers were examined. Parallel to this result obtained from the research, Kurnaz (2007) conducted a study conducted to determine the teaching and learning situations of the concept of "Energy" at the first grade of the university; he found that most of the students do not know the types of energy and that the meaningful relationship between kinetic and potential energy cannot be established with mechanical energy. It can be thought that the reason for this result may be because the pre-service science teachers learned the concept of energy with the contents containing a high level of theoretical knowledge in different courses and because of the limited lecture environments where they can learn by doing different types of energy. When the sentences written by the pre-service science teachers are examined, regarding the category of "Energy types"; "There are 3 types of energy: potential, kinetic and mechanical."; it has been determined that they have misconceptions in the form. Similar to the results of the study, Gülçiçek and Yağbasan (2004) concluded that the students did not know that the mechanical energy value of the system was the sum of the kinetic and potential energy values.

Under the category of "Scientific terms evoking the concept of energy", the pre-service teachers primarily emphasized the concepts of power, joule, speed, work, temperature, mass, calorie, atom and force. This result is an indication that pre-service teachers have information about the unit of energy, but they have confusion about concepts regarding the definition of energy. When the drawings of the pre-service science teachers were examined, it was found that no drawing was made in this category. When the sentences written by the pre-service science teachers are examined, in parallel with the results obtained from the concepts in the word association test, the "Unit of energy is Joule." while it was determined that they could write expressions containing scientific information in the form of however, it has been determined that they have misconceptions such as "Energy is the power required for an object to do work.", "Energy is the force that exists in matter in the universe." and "Energy is what is necessary for living things to move.". The reason for this situation is thought to be because the differences between the concept of "Energy" and concepts (such as power, force) at primary education, secondary education and even undergraduate level cannot be fully distinguished in the teaching process. The fact that these concepts are used interchangeably in daily life is an indicator of this. The findings showing that the pre-service science teachers confused the concept of energy with the concept of force and power, obtained in the study, support the findings obtained by different researchers (Kruger, 1990; Trumper, 1998; Tomanve Çimer, 2011; Watts; 1983). Similarly, the result that the science teacher candidates obtained in the study associated the concept of "energy" with movement was also found in Watts's (1983) study. Also, in a different study, it was found that there was a misconception among pre-service science teachers that "People gain energy by moving" (Toman \& Çimer, 2011). Trumper (1998) at the end of a 4-year study investigating the perceptions of pre-service teachers on the concept of "Energy"; it was determined that pre-service teachers' perceptions increased, but they had misconceptions about energy. Trumper found that pre-service teachers perceive energy as a tangible entity and confuse the concepts of energy and force. Bayram, Şahin, and Gürdal (1999), in their study with pre-service physics, chemistry and biology teachers who were preparing for primary education, found that the teacher candidates could not establish an inter-conceptual relationship on "Energy". 
The pre-service science teachers frequently focused on the concepts of sun, renewable energy sources, wind, non-renewable energy sources under the category of "Energy Resources". Concepts such as nonrenewable energy resources and water have been expressed very little. It is noteworthy that there is no mention of many different energy sources such as wave, hydrogen, hydroelectric, biomass, geothermal energy. This result shows that pre-service teachers do not have a sufficient level of perception on this issue. It has been determined that the concepts of wind and sun are predominantly used in the drawings of the teacher candidates. Similar to the results obtained in the study, Saraç and Bedir (2014) found that 10 classroom teachers had a lack of knowledge about renewable energy sources as a result of their research conducted to determine the perceptions of classroom teachers about renewable energy sources. In the same study, it was determined that some of the teachers confuse renewable and non-renewable energy sources. As a result of the study, it was concluded that there is a need for educational trips, materials and seminars related to the teaching of energy resources. Yildirım et al. (2019), in their study with $8^{\text {th }}$ grade students, found that although there are different energy sources, the students do not include other sources than Sun, wind and water in their drawings about these sources. This situation is an indication that the knowledge about energy resources is not at a sufficient level in secondary school and as seen at the end of the study, there is not much change at the undergraduate level. One might think that the reason for this is that the lessons are taught with the emphasis on the concepts of wind and Sun in all education level lessons on "Energy resources". When the sentences written by the pre-service science teachers are examined, regarding the "Energy resources" category; "The Sun is the most important energy source.", "There are renewable and non-renewable energy sources." and "Wind is a renewable energy source."; it was determined that they made sentences containing scientific information and did not make any sentences showing that they had misconceptions. This result shows that the pre-service science teachers have limited knowledge about the subject, but they do not have any errors.

It was determined that pre-service science teachers primarily focused on the concepts of eating, the collision of subatomic particles, breathing and friction under the category of "Situations that provides energy formation". When the drawings were examined, no drawing was found for this category. When the sentences written by pre-service science teachers are examined,"38 ATP energy is obtained as a result of breathing with oxygen."; it was determined that they made sentences containing scientific information in the form of. This result shows that the pre-service teachers have limited knowledge about the subject, but they do not have any errors. It was determined that the pre-service teachers focused primarily on the concepts of conservation, transformation and producible under the category of "Properties of energy". It is seen that a smaller number of students have expressed the concepts of consuming, saving and shopping. This situation shows that the preservice teachers have ideas about some properties of energy but they have misconceptions about some of its properties. When the drawings were examined, it was determined that they made drawings related to the concepts of conservation and transformation. The findings obtained support each other. When the sentences written by the pre-service science teachers are examined, in parallel with the results obtained from the concepts in the word association test, it has been determined that they wrote statements containing scientific information such as"Energy cannot be created from nothing and existing energy cannot be destroyed.", "Energy is converted" and "Energy is always preserved in the universe " and besides this, it has been determined that they have misconceptions in the form such as "Energy is exhausted." and "Only living things have the energy.". It is thought that the reason for this may be that the pre-service teachers did not learn the subject of energy in learning environments where they can see that energy can be transformed, not exhausted, and can make experimental practices. This situation is parallel to the findings obtained in existing studies (Kruger, 1990; Liu, Ebenezer, \& Fraser, 2002; Watts.,1983). Kruger (1990), in a study conducted with 20 elementary school teachers, researched the teachers' understanding of the concept of "Energy". It has been determined that they have misconceptions such as "Energy is about movement", "Energy is consumed", "Energy is not conserved". Watts (1983) found similar misconceptions in the study that "Only living organisms have energy".

It has been determined that pre-service teachers primarily focus on the concepts of physical activity and provide living under the category of "Contribution of energy to daily life".Fewer students used the concepts of technology and photosynthesis. When the drawings and sentences of the preservice teachers were examined, no data related to this category was found.This situation can be considered as an indication that students cannot relate the concepts they learn in lessons with daily life. In parallel with the results obtained, different studies conclude that students experience confusion of concepts between the scientific knowledge they have learned at school and the concept of energy they use in daily life (Toman \& Çimer, 2011).

It was determined that pre-service science teachers primarily focused on the concept of positive energy under the category of "Affective effect of energy". It was determined that other pre-service science teachers focused on the concepts of negative energy, love, metaphysics, dance pleasure, and coffee enjoyment. The result shows that the cognitive structures of pre-service teachers for the concept of energy, which is a versatile concept, have concepts that create a considerable affective effect. The preservice teachers did not draw for this category. When the sentences written by the science teacher candidates are examined, parallel to the results 
obtained from the concepts in the word association test, It was determined that they express non-scientific sentences containing superficial information such as "Life is beautiful thanks to positive energies.", "I have no energy today." "Energy is enjoying coffee.".This situation is an indication that pre-service science teachers cannot correctly associate scientific concepts with their life practices. Similar to the results obtained from the study, it is stated in the studies that students have difficulties in perceiving these concepts and in structuring them by associating them with daily life because some subjects and the concepts related to these subjects are mainly abstract and the theoretical part is mainly taught (Anagün, Ağır \& Kaynaş, 2010).

When all categories are examined, it is seen that the students use concepts related to physics subjects intensively about the concept of energy. However, the subject of energy is a common concept in all the subjects of physics, chemistry and biology. It has been determined that the concepts related to biology and chemistry course contents are quite limited in the cognitive structures of pre-service teachers. Köse, Bağ, and Sürücü (2006) obtained similar results in the study. In a different study, Carr and Kirkwood (1988) observed 3 teachers teaching activities related to the concept of "Energy" in biology, chemistry and physics lessons for 3 years in order to investigate teachers' perceptions about the concept of "Energy", and as a result of the research, they found that teachers teach energy limited to their fields. The results obtained show that the concept of "Energy" should be given together with the integration of physics, chemistry and biology at all levels from primary school to higher education.

The results of the study indicate that the cognitive structures of pre-service science teachers related to the concept of "Energy" should be developed more consciously and purposefully. Regarding the correct perception and use of the concept of "Energy", it can be said that the reason for the inadequacies in the cognitive structure of pre-service science teachers is the negativities they have encountered in their education process at primary and secondary education level as well as the negativities they experience during their university education. This situation is very important for prospective teachers who will become teachers. For this reason, it is extremely important to ensure correct and meaningful learning in pre-service teachers by bringing conceptual learning to the forefront at all educational levels starting from primary school. In this context, in order to give students conceptual understanding; it is suggested that primarily the science education curriculum, as well as the curriculum of physics, chemistry and biology courses, which include subjects related to the concept of energy, should be arranged in a way that enables conceptual learning. In addition, it will be effective to make sense of the concept by associating it with other lessons, providing learning environments that enable students to actively participate in the lesson and make experimental applications. As a result, qualified generations are the work of qualified teachers. For this reason, it should not be forgotten that teacher education is an issue that should be emphasized. It is thought that the results obtained from the study will contribute to similar studies in which cognitive structures are analyzed and misconceptions are determined in the future.

\section{References}

Anagün, Ş. S., Ağır, O., Kaynaş, E. (2010). İlköğretim öğrencilerinin fen ve teknoloji dersinde öğrendiklerini günlük yaşamlarında kullanım düzeyleri. [Primary school students' usage levels of science and technology course knowledge in their daily lives]. 9. Ulusal Sınıf Öğretmenliği Eğitimi Sempozyumu. Elazığ: Fırat Üniversitesi Eğitim Fakültesi.

Ayas, A., Karamustafaoğlu, S., Cerrah, L. \& Karamustafaoğlu, O. (2002). Fen bilimlerinde öğrencilerdeki kavram anlama seviyelerinde ve yanılgılarını belirleme yöntemleri üzerine bir inceleme.[An investigation on the level of conceptual understanding of students in science and the methods of determining their mistakes]. X. Ulusal Eğitim Bilimleri Kongresi, Abant İzzet Baysal Üniversitesi, Bolu.

Ayaz, E., Karakaş, H., \& Sarıkaya, R. (2016). Sınıf öğretmeni adaylarının nükleer enerji kavramına yönelik düşünceleri: bağımsız kelime ilişkilendirme örneği. [Class teacher candidates' opinions on the concept of nuclear power: the sample of independent word associaton test]. Cumhuriyet Üniversitesi FenEdebiyat Fakültesi Fen Bilimleri Dergisi, 37, 42-54.

Aydın G, Balım A. G. (2005). Yapılandırmacı yaklaşıma göre modellendirilmiş disiplinler arası uygulama: enerji konularının öğretimi. [An interdisciplinary application based on constructivist approach: teaching of energy topics]. Ankara Üniversitesi Eğitim Bilimleri Fakültesi Dergisi, 38(2), 145 - 166.

Bahar, M. (2003). Biyoloji eğitiminde kavram yanılgıları ve kavram değişim stratejileri. [Misconceptions in biology education and conceptual change strategies ]. Kuram ve Uygulamada Eğitim Bilimleri, 3(1), 27-64.

Bahar, M. \& Özatlı, S. (2003). Kelime iletişim testi yöntemi ile lise 1. sınıf öğrencilerinin canlıların temel bileşenleri konusundaki bilişsel yapılarının araştırılması.[Investigation of cognitive structures of first grade high school students about basic components of living things with word communication test method]. Balıkesir Üniversitesi Fen Bilimleri Enstitüsü Dergisi, (5), 75-85. 
Baki, A. (1999). Cebirle ilgili işlem yanılgılarının değerlendirilmesi. [Evaluation of processing errors related to algebra]. In III. Fen Bilimleri Eğitimi Sempozyumu. M.E.B. ÖYGM (pp: 46-49).

Balbağ, M. Z. (2018). Fen Bilgisi öğretmen adaylarının hız ve sürat kavramlarına ilişkin bilişsel yapıları: Kelime ilişkilendirme testi (KIT) uygulaması. [Cognitive constructs related to velocity and speed concepts of science teacher candidates: Application of word association test (WAT)]. Dicle Üniversitesi Ziya Gökalp Eğitim Fakültesi Dergisi. Issue(33),38-48.

Balbağ, M. Z., Leblebiciler, K., Karaer, G., Sarıkahya, E., \& Erkan, Ö.(2016). Türkiye'de fen eğitimi ve öğretimi sorunları. [Science education and training issues in Turkey]. Ĕgitim ve Öğretim Araştırmaları Dergisi, 5(3), 12-23.

Bayram, H., Şahin, F., \& Gürdal, A. (1999). İlköğretim öğretmen adaylarının enerji konusunda bütünlüğü sağlama ve ilişki kurma düzeyleri üzerine bir araştırma. [A research on primary school teacher candidates' levels of ensuring integrity and relationship in energy]. Buca Eğitim Fakültesi Dergisi, Özel Sayı 10.

Carr, M. \& Kirkwood, V. (1988). Teaching and learning about energy in New Zealand secondary school junior science classrooms, Physics Education, 23 (2), 86- 91.

Cardellini, L. \& Bahar, M. (2000). Monitoring the learning of chemistry through word association tests. Australian Chemistry Research Book, 19, 59- 69.

Chabalengula, V. M., Sanders, M., \& Mumba, F. (2012). Diagnosing students' understanding of energy and its related concepts in biological context. International Journal of Science and Mathematics Education, 10(2), 241-266.

Chi, M. \& Roscoe, R. (2002). The processes and challenges of conceptual change. [Electronic version]. Behavioral Science. 2, 3-27.

Çakır, S.Ö. \& Yürük, N. (1999). Oksijenli ve oksijensiz solunum konusunda kavram yanılgıları teşhis testinin geliştirilmesi ve uygulanması. [Development and application of misconceptions about oxygenated and oxygen-free breathing]. III. Fen Bilimleri Eğitimi Sempozyumu. M.E.B. ÖYGM.

Çardak, O. (2009). The determination of the knowledge level of science students on energy flow through a word association test. Energy Education Science and Technology Part B: Social and Educational Studies, l(3): 139-155.

Çetin, G., Özarslan, M., Isık, E., \& Eser, H. (2013). Students' views about health concept by drawing and writing technique. Energy Education Science and Technology, Part B, 5 (1), 597-606.

Çoban, G. Ü., Aktamış, H., \& Ergin, Ö. (2007). İlköğretim sekizinci sınıf öğrencilerinin enerjiyle ilgili görüşleri. [The views of $8^{\text {th }}$ grade students about energy]. Kastamonu Eğitim Dergisi, 15(1), 175-184.

Duit, R. (1984). Learning the energy concept in school-empirical results from the Philippines and West Germany. Physics Education, 19, 59-66.

Ekici, G. \& Kurt, H. (2014). Öğretmen adaylarının “Aids” kavramı konusundaki bilişsel yapıları: Bağımsız kelime ilişkilendirme testi örneği. [Student teachers' cognitive structure on the concept of "aids": the sample of free word association test]. Türkiye Sosyal Araştırmalar Dergisi, 3, 267-306.

Ercan, F. \& Taşdere, A. (2010). Kelime ilişkilendirme testi aracılığıyla bilişsel yapının ve kavramsal değişimin gözlenmesi. [Observing the cognitive structure and conceptual change through the word association test]. Türk Fen Eğitimi Dergisi (TÜFED), 7(2).

Güven, G \& Sülün,Y.(2018). Investigation of the effect of the interdisciplinary instructional approach on preservice science teachers' cognitive structure about the concept of energy. Necatibey Eğitim Fakültesi Elektronik Fen ve Matematik Eğitimi Dergisi (EFMED) 12, (1) 249-281.

Gussarsky, E., \& Gorodetsky, M. (1990). On the concept "chemical equilibrium: the associative framework. Journal of Research in Science Teaching, 27 (3), 197204.

Gülçiçek, Ç. \& Yağbasan, R. (2004). Basit sarkaç sisteminde mekanik enerjinin korunumu konusunda öğrencilerin kavram yanılgıları. [Students' misconceptions about conservation of mechanical energy in simple pendulum system]. Gazi Eğitim Fakültesi Dergisi, 24(3), 23-38.

Hruschka, D.J., Schwartz, D., St.John, D.C., Picone-Decaro, E., Jenkins, R.A., \& Carey, J.W. (2004). Reliability in coding open-ended data: Lessons learned from HIV behavioral research. Field Methods, 16 (3), 307331.

Karaca, G., \& Göktan, S.Ö. (2007). Ortaöğretim kimya 10 ders kitabı. [Secondary school chemistry 10 textbooks]. Paşa Yayıncılık.

Karasar, N. (1999). Bilimsel araştırma yöntemi .[Scientific research method]. Nobel Yayınları.

Kaya, E. (2017). Biyoloji öğretmen adaylarının “enzim” konusundaki bilişsel yapıları (Erzurum Örneği). [Cognitive structures of teacher candidates on "enzyme" (Erzurum Example) ]. Ekev Akademi Dergisi, 21 (72).

Kılıç, S. \& Cerit Berber, N. (2018). Fotoğraf derleme yoluyla kavram haritalama yöntemi kullanılarak öğrencilerin enerji algılarının gündelik yaşam bağlamında araştırılması. [Researching students' 
perception of energy in terms of daily life through the concept mapping method by collecting photographs]. Millî Ĕ̈itim Dergisi. 218.

Kostova, Z., \& Radoynovska, B. (2008). Word association test for studying conceptual structures of teachers and students. Bulgarian Journal of Science and Education Policy, 2 (2), 209-231.

Köse, S., Bağ, H., Sürücü, A. \& Uçak, E. (2006). Prospective science teacher' about energy, International Journal of Environmental and Science Education, 1,(2) 141-152.

Köseoğlu, F. \& Bayır, E. (2011). Kelime ilişkilendirme test yöntemiyle kimya öğretmen adaylarının gravimetrik analize ilişkin bilişsel yapılarının incelenmesi. [Investigation of cognitive structures of pre-service chemistry teachers related to gravimetric analysis with word association test method]. Trakya Üniversitesi Ĕ̈itim Fakültesi Dergisi 1 (1), 107-125.

Kruger, C. (1990). Some primary teachers' side as about energy. Physics Education 25, 86-91.

Kurnaz, M. A. (2007). Enerji kavramının üniversite 1. sınıf seviyesinde öğrenim durumlarının analizi. [Analysis of the education situation of the energy concept at the first year level of the university]. Yüksek lisans tezi. Karadeniz Teknik Üniversitesi, Eğitim Bilimleri Enstitüsü: Trabzon.

Kurt, H. (2013). Biology student teachers' cognitive structure about "Living thing". Educational Research and Reviews, 8 (12), 871-880.

Kurt, H., Ekici, G., Aktaş, M. \& Aksu, Ö.(2013).Determining biology student teachers cognitive structure on the concept of "diffusion" through the free word association test and the drawing-writing Technique. International Education Studies, 6(9),187-206.

Lichtman, M. (2010). Qualitative research in education. Los Angeles: Sage Publications, Inc.

Lin, Chen-Yung \& Reping Hu. (2003) "Students' understanding of energy flow and matter cycling in the context of the food chain, photosynthesis, and respiration." Int. J. Sci. Educ. 25.12 (2003): 1529-1544.

Liu, X., Ebenezer, J. \&Fraser, D. M. (2002). Structural characteristics of university engineering students' conceptions of energy, Journal of Research in Science Teaching, 39, (5), 423-441.

Marulcu, İ. \& Höbek, K. M. (2014). "8. Sınıflara alternatif enerji kaynaklarının mühendislik dizayn metodu ile ögretimi". [Teaching alternate energy sources to 8 th grades students by engineering design method]. Middle Eastern and African Journal of Educational Research, 9, 41- 58.

Miles, M.B., \& Huberman, A. M. (1994). Qualitative data analysis. Thousand Oaks, CA: Sage.

Nakiboglu, C. (2008). Using word associations for assessing non-major science students' knowledge structure before and after general chemistry instruction: the case of atomic structure. Chemistry Education Research and Practice, 9 (4), 309-322.

Nartgün, Z. (2006). Fen ve teknoloji öğretiminde ölçme ve değerlendirme. [Measurement and evaluation in science and technology teaching]. Bahar, M. (Ed), Fen ve Teknoloji Öğretimi. Pegema Yayıncılık.

Nussbaum, J. \& Novick, S. (1982). Alternative frameworks, conceptual conflict and accommodation: Toward a principled teaching strategy. Instructional science.

Nyachwayaa, J.M., Mohameda, A.R., Roehriga, G.H., Woodb, N.B., Kernc, A.L .\& Schneiderd, J.L.(2011).The development of an open ended drawing tool: An alternative diagnostic tool for assessing students' understanding of the particulate nature of matter. Chemistry Education Research and Practice, 12(2), 121-132.

Opitz, S. T., Harms, U., Neumann, K., Kowalzik, K. \& Frank, A. (2015). Students' energy concepts at the transition between primary and secondary school. Research in Science Education, 45(5), 691-715.

Opitz, S. T., Blankenstein, A., \& Harms, U. (2017). Student conceptions about energy in biological contexts. Journal of Biological Education, 51(4), 427-440.

Özden, M. (2009). Primary student teachers' ideas of atoms and molecules: Using drawings. Education, 129(4), 635-642.

Patrick, P. G. \& Tunnicliffe, S. D. (2010). Science teachers' drawings of what is inside the human body. Journal of Biological Education, 44(2), 81-87.

Pluhar, Z. F., Piko, B. F., Kovacs, S. \& Uzzoli, A. (2009). Air pollution is bad for my health: Hungarian children's knowledge of the role of environment in health and disease. Health \& Place, 15, 239-246.

Reiss, M. J., \& Tunnicliffe, S.D. (2001). Students' understandings of human organs and organ systems. Research in Science Education, 31, 383-399.

Roberts, P., \& Priest, H. (2006). Reliability and validity in research. Nursing Standard, 20, 41-45.

Sağlam Arslan, A. (2010). Cross-grade comparison of students' understanding of energy concepts. Journal of Science Educational Technology, 19, 303-313.

Sağdıç, D., Bulut, Ö., Korkmaz, S., Börü, S., Öztürk, E., \& Cavak, Ş. (2007). Ortaöğretim 10. sınıf biyoloji. (2. Baskl) [Secondary school 10th grade biology. (2nd Edition)]. MEB. Yayınları.

Saraç, E., \& Bedir, H. (2014). Sınıf öğretmenlerinin yenilenebilir enerji kaynakları ile ilgili algıları üzerine nitel bir çalışma. [Primary school teachers related to perceptions of renewable energy sources on the qualitative research]. Kara Harp Okulu Bilim Dergisi, 24(1), 19-45. 
Sarıca, R. \& Çetin, B. (2012). Öğretimde kavram haritaları kullanımının öğrencilerin akademik başarısına ve kalıcılığa etkisi. [The effects of using concept maps on achievement and retention in teaching science lessons]. Ilkögretim Online, 11(2), 306-318.

Shavelson, R. J. (1974). Methods for examining representations of a subject-matter structure in a student's memory. Journal of Research in Science Teaching, 11(3), 231-249.

Skelly, K.M., \& Hall, D. (1993). The development and validation of categorization of sources of misconceptions in chemistry. Paper presented at the Third International Seminar on Misconceptions and Educational Strategies in science and Mathematics, Ithaca.

Smith, K.J. \& Metz, P.A. (1996). Evaluating student understanding of solution chemistry through microscopic representations. Journal of Chemical Education. 73 (3), 233-235.

Solomon, J. (1982). How children learn about energy or do the first law come first? School Science Review, 63(224), 415-422.

Stavridou, H., Solomonidou, C. (1998). Conceptual reorganization and the construction of the chemical reaction concept during secondary education. International journal of science.

Stylianidou, F. (2002). Analysis of science textbook pictures about energy and pupils' readings of them. International Journal of Science Education .

Şahan, B.Y. \& Tekin, L. (2007). Ortaögretim 10. sınıf fizik ders kitabı. [Secondary school 10th grade physics textbook].Zambak Yayınları.

Şimşek, M. (2013). Sosyal bilgiler öğretmen adaylarının coğrafi bilgi sistemleri (CBS) konusundaki bilişsel yapılarının ve alternatif kavramlarının kelime ilişkilendirmesi testi ile belirlenmesi. [Determining the cognitive structures and alternative concepts of social studies teacher candidates about geographical information systems by word association test].4. Ulusal ilköğretim bölümleri öğrenci kongresi, 8-9 Kasım 2013 Nevşehir Üniversitesi, Nevşehir.

Tavşanc1l, E., \& Aslan, E. (2001). İçerik analizi ve uygulama örnekleri. [Content analysis and application examples ]. Epsilon Yayınları.

Thomas, G. V., \& Silk, A. M. J. (1990). An introduction to the psychology of children's drawings. Hemel Hemstead, UK: Harvester Wheatsheaf.

Töman, U. \& Cimer, O. S. (2011). Enerji kavramının farklı öğrenim seviyelerinde öğrenilme durumunun araştırılması. [An investigation into the conceptions of energy at different educational levels]. Bayburt Üniversitesi Eğitim Fakültesi Dergisi 6, (I-II),23.

Töman, U. \& Odabaşı, O. S. (2012). Enerji dönüşümü kavramının farklı öğrenim seviyelerinde öğrenilme durumunun araştırılması. [An investigation into the conception energy conversion at different educational levels]. Erzincan Üniversitesi Eğitim Fakültesi Dergisi, 14 (2), 289-312.

Toman, U., Karatas, O. F. \& Cimer, O. S. (2016). Development and implementation of a standard test to diagnose misconceptions about energy and related concepts: The beginning. Bayburt Egitim Fakultesi Dergisi, 8(1), 116-134.

Trumper, R. A. (1990). Being constructive: An alternative approach to the teaching of the energy concept-part one. International journal of science education, 12(4), 343-354.

Trumper, R. (1996). Survey of Israeli physics students' conceptions of energy in pre-service training for high school teachers. Research in Science and Technological Education 14: 179-192.

Trumper, R. A. (1998). A longitudinal study of physics students' conceptions on energy in pre-service training for high school teachers. Journal of Science Education Technology, 7(4), 311-318.

Trefil, J., \& Hazen, R.M. (2004). Physics matters an introduction to conceptual physics. Wiley, New York.

Tsai, C. C., \& Huang, C. M. (2002). Exploring students' cognitive structures in learning science: a review of relevant methods. Journal of Biological Education, 36(4), 163-169.

Uyduran, G. (2019). Ortaokul öğrencilerinin “enerji” konusundaki bilişsel yapılarının kelime ilişkilendirme testi (kit) yoluyla incelenmesi. [ Investigation of middle school students' cognitive structures about "energy" through word association test (WAT) ].Yüksek Lisans Tezi. Ömer Halisdemir Üniversitesi Eğitim Bilimleri Enstitüsü. Niğde.

Ünal Çoban G., Aktamış H. \& Ergin Ö. (2007) İlköğretim 8. sınıf öğrencilerinin enerjiyle ilgili görüşleri. [The views of $8^{\text {th }}$ grade students about energy. ] G. U. Kastamonu Ĕgitim Dergisi, 15(1), 175-184.

Watt, D., M.(1983). Some alternative views of energy. Physics Education, 18, 213-217.

Yağbasan, R. \& Gülçiçek, Ç. (2003). Fen öğretiminde kavram yanılgılarının karakteristiklerinin tanımlanması. [Describing the characteristics of misconceptions in science teaching]. Pamukkale Üniversitesi Eğitim Fakültesi Dergisi ,(1) 13.

Yayla, R. G., \& Eyceyurt, G. (2011). Mental models of pre-service science teachers about basic concepts in chemistry. Western Anatolia Journal of Educational Sciences, 285-294

Yıldırım, A., \& Şimşek, H. (2016). Soysal bilimlerde nitel araştırma yöntemleri. [Qualitative research methods in the social sciences].Seçkin Yayıncılık. 
Yıldırım, T., Önal, N., Büyük, U. (2019). Sekizinci sınıf öğrencilerinin yenilenebilir enerji kaynaklarına ilişkin algılarının bilim karikatürleri aracılığılla incelenmesi. [Investigation of eighth grade students' renewable energy resources perceptions by science cartoons]. Kuramsal Eğitimbilim Dergisi, 12(1), 342-368.

Yuenyong, C., \& Yuenyong, J. (2007). Grade 1 to 6 Thai Students' existing ideas about energy. Science Education International, 18(4), 289-298.

Yürümezoğlu, K., Ayaz, S. \& Çökelez, A. (2009). Grade 7-9 students' perceptions of energy and related concepts. Necatibey Faculty of Education Electronic Journal of Science and Mathematics Education, 3(2), 52-73. 